\title{
Analisis Pengukuran Beban Kerja Supervisor Dan Fireman PT Perta Arun Gas Menggunakan Metode Defence Research Agency Workload Scale
}

\author{
Cut Ita Erliana* dan Sri Mawaddah \\ Jurusan Teknik Industri, Fakultas Teknik, Universitas Malikussaleh, Aceh Utara, Indonesia \\ *Corresponding Author : cutitha@unimal.ac.id
}

\begin{abstract}
Abstrak - Pengukuran beban kerja merupakan suatu teknik untuk mendapatkan informasi tentang efisiensi dan efektifitas kerja suatu unit organisasi, atau pemegang jabatan melalui proses penelitian dan pengkajian yang dilakukan dengan menggunakan teknik analisis jabatan, teknik analisis beban kerja atau teknik manajemen lainnya. Departemen Health Safety Enviromental (HSE) \& Quality Management (QM) merupakan salah satu departemen yang ada di PT Perta Arun Gas. Total Karyawan di departemen/fungsi HSE \& QM adalah sebanyak 73 orang termasuk didalamnya personel fireman, dengan jam kerja dari pukul 07.00 s/d 16.00 WIB. Selama ini perusahaan belum pernah melakukan pengukuran beban kerja bagi karyawan/pekerja yang ada di departemen/fungsi HSE \& QM. Melalui pengukuran beban kerja, maka akan diketahui apakah beban kerja seorang pegawai sudah optimal atau sudah berlebihan, dimana akan berpengaruh terhadap hasil kinerja pegawai yang dihasilkan. Berdasarkan hasil perhitungan dengan metode DRAWS diketahui rata-rata skor beban kerja yang diperoleh untuk Supervisor sebesar 52,80\% (pada kategori beban kerja optimal load), dimana variabel beban kerja yang dominan adalah time pressure sebesar $36 \%$, dengan sebaran beban kerja fisik sebesar $46,8 \%$ dan beban kerja mental sebesar 53,2\%. Sementara untuk fireman diperoleh rata-rata skor beban kerja sebesar $48,63 \%$ (pada kategori beban kerja optimal load), dimana variabel beban kerja yang dominan adalah Central Demand sebesar 27,44\% dengan sebaran beban kerja fisik sebesar 47,81\% dan beban kerja mental sebesar 49,52\%. Dengan demikian, beban kerja mental yang dirasakan oleh Supervisor lebih besar dari beban kerja fisiknya begitu juga yang dirasakan oleh personel fireman dimana lebih didominasi oleh beban kerja mental.
\end{abstract}

Kata Kunci : Beban, Kerja, DRAWS.

\section{Pendahuluan}

Dari sudut pandang ergonomi, setiap beban kerja yang diterima oleh seseorang harus sesuai dan seimbang baik terhadap kemampuan fisik, kemampuan kognitif maupun keterbatasan manusia menerima beban tersebut [1] [2].

Kemampuan kerja seorang tenaga kerja berbeda dari satu dengan yang lainnya tergantung dari tingkatan keterampilan, keseragaman jasmani, keadaan gizi, jenis kelamin, usia dan ukuran tubuh dari pekerjaan yang bersangkutan [3] [4].

Manusia sebagai operator dalam melakukan pekerjaannya memiliki keterbatasan. Dengan adanya keterbatasan, tidak menutup kemungkinan akan terjadinya kesalahan operator dalam melakukan pekerjaannya. Kesalahan kerja yang terjadi salah satu penyebabnya adalah karena adanya beban pekerjaan yang tidak dapat dikerjakan dengan baik oleh pekerjanya [5].

Beban kerja diterima oleh tubuh akibat melaksanakan suatu aktivitas kerja kerja baik berupa beban fisik dan mental yang menjadi tanggung jawabnya. Perhitungan beban kerja disuatu perusahaan merupakan kegiatan yang harus dilakukan perusahaan dalam menjaga kinerja pegawainya agar tetap baik [6] [7].

Departemen Health Safety Enviromental (HSE) \& Quality Management (QM) [8] merupakan salah satu departemen yang ada di PT Perta Arun Gas. Total Karyawan di departemen/fungsi HSE \& QM adalah sebanyak 73 orang termasuk didalamnya personel fireman, dengan jam kerja dari pukul $07.00 \mathrm{~s} / \mathrm{d} 16.00$ WIB. Selama ini perusahaan belum pernah melakukan pengukuran beban kerja bagi karyawan/pekerja yang ada di departemen/fungsi HSE \& QM, maka dari itu diperlukan pengukuran beban kerja untuk menjaga kinerja dari karyawan yang berada di departemen HSE \& QM [9] [10]. 


\section{Tinjauan Pustaka}

\section{Beban Kerja}

Tubuh manusia dirancang untuk dapat melakukan aktivitas pekerjaan sehari-hari. Adanya massa otot yang bobotnya hampir lebih dari separuh beban tubuh, memungkinkan kita untuk dapat menggerakkan dan melakukan pekerjaan. Pekerjaan di satu pihak mempunyai arti penting bagi kemajuan dan peningkatan prestasi, sehingga mencapai kehidupan yang produktif sebagai satu tujuan hidup. Di pihak lain, bekerja berarti tubuh akan menerima beban dari luar tubuhnya. Dengan kata lain bahwa setiap pekerjaan merupakan beban bagi yang bersangkutan. Beban tersebut dapat berupa beban fisik maupun mental [11].

Workload atau beban kerja merupakan usaha yang harus dikeluarkan oleh seseorang untuk memenuhi permintaan dari pekerjaan tersebut. Sedangkan kapasitas adalah kemampuan/kapasitas manusia. Kapasitas ini dapat diukur dari kondisi fisik maupun mental seseorang. Beban kerja yang dimaksud adalah ukuran (porsi) dari kapasitas operator yang terbatas yang dibutuhkan untuk melakukan kerja tertentu [12].

\section{Kerja Fisik dan Mental \\ Kerja Fisik}

Kerja fisik adalah kerja yang memerlukan energi fisik otot manusia sebagai sumber tenaganya (power). Kerja fisik disebut juga "manual operation" dimana performa kerja sepenuhnya akan tergantung pada manusia yang berfungsi sebagai sumber tenaga (power) ataupun pengendali kerja. Kerja fisik juga dapat dikonotasikan dengan kerja berat atau kerja kasar karena kegiatan tersebut memerlukan usaha fisik manusia yang kuat selama periode kerja berlangsung. Dalam kerja fisik konsumsi energi merupakan faktor utama yang dijadikan tolak ukur penentu berat dan ringannya suatu pekerjaan [13].

\section{Kerja Mental}

Kerja mental merupakan kerja yang melibatkan proses berpikir dari otak kita. Pekerjaan ini akan mengakibatkan kelelahan mental bila kerja tersebut dalam kondisi yang lama, bukan diakibatkan oleh aktivitas fisik secara langsung melainkan akibat kerja otak kita [14].

\section{Pengukuran Beban Kerja Dengan Metode DRAWS}

Metode DRAWS (Defence Research Agency Workload Scale) merupakan salah satu dari metode pengukuran beban kerja subjektif. Metode ini hanya melibatkan empat variabel skala pengukuran, dimana lebih mudah dan cepat dalam pengumpulan datanya dibandingkan dengan metode NASA-TLX yang melibatkan enam variabel skala pengukuran. Sedangkan metode SWAT adalah sangat rumit dan subjektivitas responden yang tinggi dalam pengumpulan data, dimana harus menilai pekerjaaannya dan mengurutnya melalui kartu penilaian sebanyak 27 kartu [15] [16].

Metode ini merupakan teknik untuk mengukur mental workload secara subjektif dengan tujuan untuk mengetahui beban kerja yang didasarkan pada dimensi yang terbentuk. Metode DRAWS (Defence Research Agency Workload Scale) ini merupakan teknik penilaian beban kerja multidimensional yang mirip dengan metode NASA-TLX yang melibatkan responden untuk dilakukan penilaian secara subjektif melalui pertanyaan dari empat variabel yang berbeda untuk memperoleh skor beban kerja secara keseluruhan [17].

Empat variabel beban kerja pada pengamatan dengan metode DRAWS (Defence Research Agency Workload Scale) tersebut diantaranya yaitu [18]:

1. Input Demand (merupakan beban yang terkait dengan perolehan informasi dari sumber eksternal yang diamati).

2. Central Demand (merupakan beban yang terkait dalam penafsiran informasi, mental dan proses dalam memutuskan tindakan terhadap tugas).

3. Output Demand (merupakan beban yang terkait dengan tindakan fisik atau lisan dalam suatu tugas).

4. Time Pressure (merupakan beban yang terkait dengan kendala yang berhubungan dengan tekanan waktu terhadap karyawan dalam bertindak cepat).

Keempat variabel ini merupakan rangkaian yang dirasakan oleh pekerja yang menimbulkan beban kerja mental pada pekerjaan yang mereka kerjakan, dimana keterkaitan variabelnya seperti paradigma proses manufaktur, yaitu terdapat Input (material, manusia, mesin, modal, metode), kemudian Process (proses manufaktur yang mentransformasi bahan baku menjadi produk jadi) dan menghasilkan Output (produk jadi yang siap dikirim ke pelangggan). Secara umum paradigm model yang digunakan dalam pemecahan masalah [19]. Kuesioner penelitian beban kerja ini terdiri dari :

1. Deskripsi pekerjaan tehadap variable beban kerja DRAWS (Defence Research Agency Workload Scale).

2. Penilaian beban kerja terhadap variable DRAWS (Defence Research Agency Workload Scale).

3. Pembobotan terhadap tingkat kepentingan pada variabel beban kerja DRAWS (Defence Research Agency Workload Scale).

Tingkatan untuk penilaian beban kerja dibagi menjadi lima kategori, yaitu sebagai berikut :
1. Sangat rendah: $0 \%-20 \%$
2. Rendah : $20,1 \%-40 \%$
3. Sedang : $40,1 \%-60 \%$
4. Tinggi : $60,1 \%-80 \%$
5. Sangat Tinggi : $80,1 \%-100 \%$ 
Total skor beban kerja diperoleh dari hasil perkalian antara hasil penilaian beban kerja dengan hasil pembobotan tingkat kepentingan variabel beban kerja.

Adapun Penentuan skor untuk beban kerja terhadap variabel DRAWS (Defence Research Agency Workload Scale) terdiri dari tiga kategori beban kerja dimulai dari skor $\leq 40 \%$ yaitu termasuk kedalam kategori beban kerja underload, selanjutnya $40 \%$ < skor $\leq 60 \%$ yaitu termasuk kedalam kategori beban kerja optimal load, dan yang terakhir adalah skor > 60\% yaitu termasuk kedalam kategori beban kerja overload [20].

\section{Metodelogi Penelitian}

Adapun skema yang dilakukan dalam melakukan penelitian yaitu sebagai berikut :

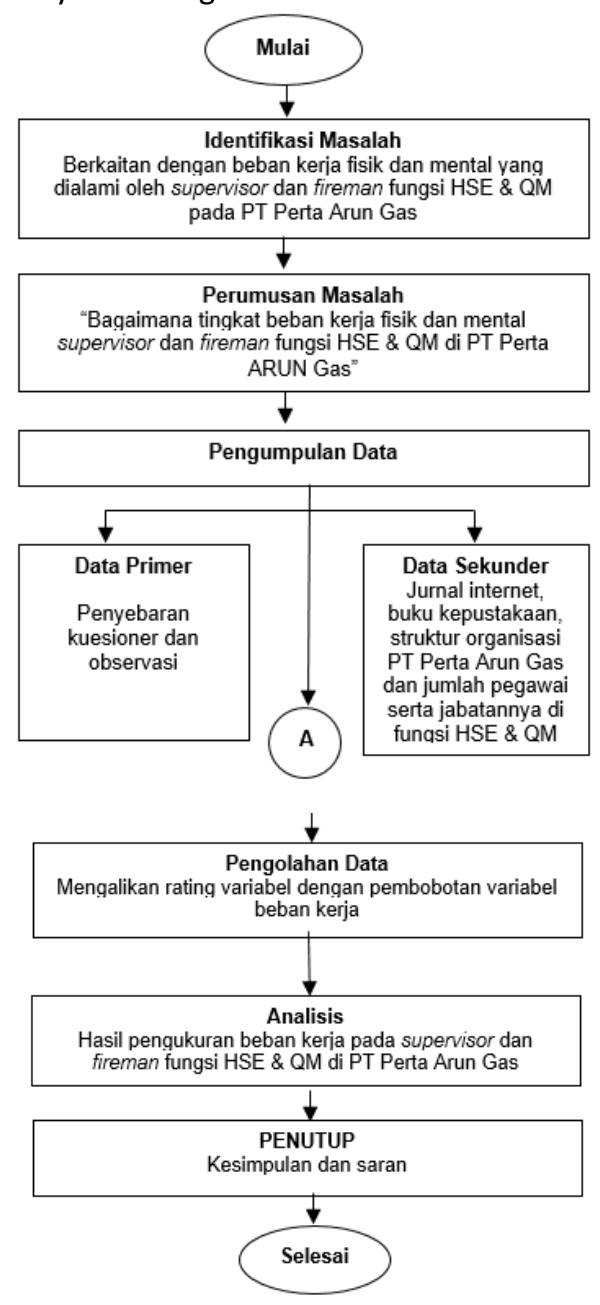

Gambar 1. Skema Metodelogi Penelitian

\section{Hasil Dan Pembahasan}

Berdasarkan pembagian kuesioner yang dibagikan di fungsi HSE \& QM didapatkan hasil rekapitulasi penilaian beban kerja dan pembobotan variabel beban kerja sebagai berikut :

\section{Supervisor}

Tabel 1 Hasil Rekapitulasi Penilaian Beban Kerja DRAWS untuk Supervisor

\begin{tabular}{|c|c|c|c|c|c|}
\hline \multicolumn{6}{|c|}{ Penilaian Variabel Beban Kerja DRAWS } \\
\hline NO & Jabatan & $\begin{array}{c}\text { Input } \\
\text { Demand } \\
\text { (ID) }\end{array}$ & $\begin{array}{c}\text { Central } \\
\text { Demand } \\
\text { (CD) }\end{array}$ & $\begin{array}{c}\text { Output } \\
\text { Demand } \\
\text { (OD) }\end{array}$ & $\begin{array}{c}\text { Time } \\
\text { Pressure } \\
\text { (TP) }\end{array}$ \\
\hline 1 & F/S Supv & 85 & 85 & 80 & 90 \\
\hline
\end{tabular}

Tabel 2 Hasil Rekapitulasi Penilaian Beban Kerja DRAWS untuk Supervisor (lanjutan)

\begin{tabular}{|c|c|c|c|c|c|}
\hline \multicolumn{6}{|c|}{ Penilaian Variabel Beban Kerja DRAWS } \\
\hline NO & Jabatan & $\begin{array}{c}\text { Input } \\
\text { Demand } \\
\text { (ID) }\end{array}$ & $\begin{array}{c}\text { Central } \\
\text { Demand } \\
\text { (CD) }\end{array}$ & $\begin{array}{c}\text { Output } \\
\text { Demand } \\
\text { (OD) }\end{array}$ & $\begin{array}{c}\text { Time } \\
\text { Pressure } \\
\text { (TP) }\end{array}$ \\
\hline 2 & Shift Supv & 67,5 & 55 & 65 & 60 \\
\hline 3 & F/S Supv & 20 & 15 & 25 & 17,5 \\
\hline 4 & $\begin{array}{c}\text { F/S Shift } \\
\text { Supv }\end{array}$ & 20 & 20 & 20 & 20 \\
\hline 5 & $\begin{array}{c}\text { Supv Env \& } \\
\text { OH }\end{array}$ & 60 & 85 & 80 & 77,5 \\
\hline
\end{tabular}

Tabel 3 Hasil Rekapitulasi Pembobotan Variabel Beban Kerja DRAWS untuk Supervisor

\begin{tabular}{|c|c|c|c|c|c|c|}
\hline \multicolumn{7}{|c|}{ Pembobotan Variabel Beban Kerja DRAWS } \\
\hline NO & Jabatan & $\begin{array}{c}\text { Input } \\
\text { Demand } \\
\text { (ID) }\end{array}$ & $\begin{array}{c}\text { Central } \\
\text { Demand } \\
\text { (CD) }\end{array}$ & $\begin{array}{c}\text { Output } \\
\text { Demand } \\
\text { (OD) }\end{array}$ & $\begin{array}{c}\text { Time } \\
\text { Pressure } \\
\text { (TP) }\end{array}$ & $\begin{array}{c}\text { Jumlah } \\
(\%)\end{array}$ \\
\hline 1 & $\begin{array}{c}\text { F/S } \\
\text { Supv }\end{array}$ & 22 & 16 & 22 & 40 & 100 \\
\hline 2 & $\begin{array}{c}\text { Shift } \\
\text { Supv }\end{array}$ & 35 & 15 & 30 & 20 & 100 \\
\hline 3 & $\begin{array}{c}\text { F/S } \\
\text { Supv }\end{array}$ & 20 & 20 & 20 & 40 & 100 \\
\hline 4 & $\begin{array}{c}\text { F/S } \\
\text { Shift } \\
\text { Supv }\end{array}$ & 20 & 20 & 20 & 20 & 100 \\
\hline 5 & $\begin{array}{c}\text { Supv } \\
\text { Env \& } \\
\text { OH }\end{array}$ & 20 & 15 & 25 & 40 & 100 \\
\hline
\end{tabular}

\section{Fireman}

Tabel 4 Hasil Rekapitulasi Penilaian Beban Kerja DRAWS untuk Fireman

\begin{tabular}{|c|c|c|c|c|}
\hline \multicolumn{5}{|c|}{ Penilaian Variabel Beban Kerja DRAWS } \\
\hline $\begin{array}{c}\text { Input } \\
\text { Demand } \\
\text { (ID) }\end{array}$ & $\begin{array}{c}\text { Central } \\
\text { Demand } \\
(\text { CD })\end{array}$ & $\begin{array}{c}\text { Output } \\
\text { Demand } \\
(\text { OD })\end{array}$ & $\begin{array}{c}\text { Time } \\
\text { Pressure } \\
(\text { TP })\end{array}$ \\
\hline 1 & 59 & 64,5 & 58 & 66 \\
\hline 2 & 17,5 & 20 & 12,5 & 12,5 \\
\hline 3 & 15 & 17,5 & 30 & 25 \\
\hline 4 & 80,1 & 70,1 & 80,1 & 80,1 \\
\hline 5 & 80,1 & 80,1 & 80,1 & 80,1 \\
\hline 6 & 85,5 & 78 & 85,5 & 85,5 \\
\hline 7 & 80 & 100 & 80 & 90 \\
\hline 8 & 20 & 17,5 & 32,5 & 27,5 \\
\hline 9 & 17,5 & 20 & 32,5 & 35 \\
\hline 10 & 15 & 17,5 & 37,55 & 22,5 \\
\hline 11 & 12,5 & 15 & 15 & 12,5 \\
\hline 12 & 12,5 & 10 & 15 & 10 \\
\hline 13 & 12,5 & 12,5 & 10 & 12,5 \\
\hline 14 & 60,1 & 70,1 & 60,1 & 60,1 \\
\hline 15 & 59 & 59 & 60 & 66,5 \\
\hline 16 & 80 & 100 & 80 & 90 \\
\hline 17 & 85,5 & 85,5 & 85,5 & 85,5 \\
\hline
\end{tabular}

Tabel 5 Hasil Rekapitulasi Pembobotan Variabel Beban Kerja DRAWS untuk Fireman

\begin{tabular}{|c|c|c|c|c|c|}
\hline \multicolumn{6}{|c|}{ Pembobotan Variabel Beban Kerja DRAWS } \\
\hline NO & $\begin{array}{c}\text { Input } \\
\text { Demand } \\
(\text { ID) }\end{array}$ & $\begin{array}{c}\text { Central } \\
\text { Demand } \\
\text { (CD) }\end{array}$ & $\begin{array}{c}\text { Output } \\
\text { Demand } \\
\text { (OD) }\end{array}$ & $\begin{array}{c}\text { Time } \\
\text { Pressure } \\
(\text { TP })\end{array}$ & $\begin{array}{c}\text { Jumlah } \\
(\%)\end{array}$ \\
\hline 1 & 25 & 35 & 20 & 20 & 100 \\
\hline 2 & 20 & 31 & 32 & 17 & 100 \\
\hline 3 & 20 & 30 & 30 & 20 & 100 \\
\hline 4 & 25 & 25 & 25 & 25 & 100 \\
\hline 5 & 25 & 25 & 25 & 25 & 100 \\
\hline 6 & 25 & 25 & 25 & 25 & 100 \\
\hline 7 & 30 & 30 & 30 & 10 & 100 \\
\hline 8 & 20 & 30 & 20 & 30 & 100 \\
\hline 9 & 20 & 30 & 30 & 20 & 100 \\
\hline 10 & 20 & 30 & 30 & 20 & 100 \\
\hline
\end{tabular}




\begin{tabular}{|l|l|c|c|c|c|}
\hline 11 & 20 & 15,5 & 16 & 8,5 & 100 \\
\hline 12 & 25 & 20 & 30 & 20 & 100 \\
\hline 13 & 25 & 25 & 25 & 25 & 100 \\
\hline 14 & 20 & 30 & 20 & 30 & 100 \\
\hline 15 & 15 & 30 & 25 & 30 & 100 \\
\hline 16 & 25 & 30 & 25 & 15 & 100 \\
\hline 17 & 25 & 25 & 20 & 30 & 100 \\
\hline
\end{tabular}

\section{Pengolahan Data}

Berdasarkan data yang telah didapatkan daripada pengumpulan data diatas, maka dilakukan pengolahan data yaitu sebagai berikut :

\section{Supervisor}

Adapun hasil perhitungan rekapitulasi penilaian variabel beban kerja dangan pembobotan variabel beban kerja Supervisor dapat dilihat pada tabel 6 dan kategori beban kerja untuk supervisor dari rata-rata pembobotan variabel beban kerja dapat dilihat pada tabel 7 dibawah ini:

Tabel 6 Hasil Perhitungan Rekapitulasi Skor Beban Kerja dengan Menggunakan Metode DRAWS untuk Supervisor

\begin{tabular}{|c|c|c|c|c|c|c|}
\hline \multirow{2}{*}{ Jabatan } & \multicolumn{4}{|c|}{ Skoring } & \multirow{2}{*}{$\begin{array}{c}\text { Total } \\
\text { Skoring } \\
(\%)\end{array}$} & \multirow{2}{*}{$\begin{array}{c}\text { Kategori } \\
\text { Beban } \\
\text { Kerja }\end{array}$} \\
\hline & $\begin{array}{c}\text { Input } \\
\text { Demand }\end{array}$ & $\begin{array}{c}\text { Central } \\
\text { Demand }\end{array}$ & $\begin{array}{c}\text { Output } \\
\text { Demand }\end{array}$ & $\begin{array}{c}\text { Time } \\
\text { Pressure }\end{array}$ & & \\
\hline \multirow{2}{*}{$\begin{array}{l}\text { F/S } \\
\text { Supv }\end{array}$} & $85 \times 22$ & $85 \times 16$ & $80 \times 22$ & $90 \times 40$ & \multirow{2}{*}{85,90} & \multirow{2}{*}{$\begin{array}{l}\text { Over } \\
\text { Load }\end{array}$} \\
\hline & 1870 & 1360 & 1760 & 3600 & & \\
\hline \multirow{2}{*}{$\begin{array}{l}\text { Shift } \\
\text { Supv }\end{array}$} & $67,5 \times 35$ & $55 \times 15$ & $65 \times 30$ & $60 \times 20$ & \multirow{2}{*}{63,37} & \multirow{2}{*}{$\begin{array}{l}\text { Over } \\
\text { Load }\end{array}$} \\
\hline & 2362,5 & 825 & 1950 & 1200 & & \\
\hline \multirow{2}{*}{$\begin{array}{l}\text { F/S } \\
\text { Supv }\end{array}$} & $20 \times 20$ & $15 \times 20$ & $25 \times 20$ & $17,5 \times 40$ & \multirow{2}{*}{19} & \multirow{2}{*}{$\begin{array}{l}\text { Under } \\
\text { Load }\end{array}$} \\
\hline & 400 & 300 & 500 & 700 & & \\
\hline \multirow{2}{*}{$\begin{array}{l}\text { F/S } \\
\text { Shift } \\
\text { Supv }\end{array}$} & $20 \times 20$ & $20 \times 20$ & $20 \times 20$ & $20 \times 40$ & \multirow[b]{2}{*}{20} & \multirow{2}{*}{$\begin{array}{l}\text { Under } \\
\text { Load }\end{array}$} \\
\hline & 400 & 400 & 400 & 800 & & \\
\hline \multirow{2}{*}{$\begin{array}{c}\text { Supv } \\
\text { Env \& } \\
\mathrm{OH}\end{array}$} & $60 \times 20$ & $85 \times 15$ & $80 \times 25$ & $77,5 \times 40$ & \multirow[b]{2}{*}{75,75} & \multirow{2}{*}{$\begin{array}{l}\text { Over } \\
\text { Load }\end{array}$} \\
\hline & 1200 & 1275 & 2000 & 3100 & & \\
\hline \multicolumn{5}{|c|}{ Rata-Rata } & 52,80 & $\begin{array}{c}\text { Optimal } \\
\text { Load }\end{array}$ \\
\hline
\end{tabular}

Tabel 7 Kategori Beban Kerja Untuk Supervisor

\begin{tabular}{|c|c|c|c|c|c|}
\hline \multicolumn{6}{|c|}{ Kategori Beban Kerja } \\
\hline \multirow[b]{2}{*}{ Jabatan } & \multicolumn{2}{|c|}{ Beban Kerja Fisik } & \multicolumn{2}{|c|}{$\begin{array}{c}\text { Beban Kerja } \\
\text { Mental }\end{array}$} & \multirow[b]{2}{*}{$\begin{array}{c}\text { Jumlah } \\
(\%)\end{array}$} \\
\hline & $\begin{array}{c}\text { Rata- } \\
\text { Rata } \\
\text { Input } \\
\text { Deman } \\
d \text { (ID) }\end{array}$ & $\begin{array}{l}\text { Rata- } \\
\text { Rata } \\
\text { Output } \\
\text { Deman } \\
d(\mathrm{OD})\end{array}$ & $\begin{array}{c}\text { Rata- } \\
\text { Rata } \\
\text { Central } \\
\text { Deman } \\
d(C D)\end{array}$ & $\begin{array}{c}\text { Rata- } \\
\text { Rata } \\
\text { Time } \\
\text { Pressur } \\
\text { e (TP) }\end{array}$ & \\
\hline Supervisor & 23,4 & 23,4 & 17,2 & 36 & 100,00 \\
\hline $\begin{array}{l}\text { Total Rata- } \\
\text { Rata }\end{array}$ & \multicolumn{2}{|c|}{46,8} & \multicolumn{2}{|c|}{53,2} & 100 \\
\hline
\end{tabular}

\section{Fireman}

Adapun hasil perhitungan rekapitulasi penilaian variabel beban kerja dangan pembobotan variabel beban kerja Fireman dapat dilihat pada tabel 8 dan kategori beban kerja untuk supervisor dari rata-rata pembobotan variabel beban kerja dapat dilihat pada tabel 9 dibawah ini:

Tabel 8 Hasil Rekaptulasi Skor Beban Kerja dengan Menggunakan Metode DRAWS untuk Fireman

\begin{tabular}{|c|c|c|c|c|c|c|}
\hline \multirow{3}{*}{ No } & \multicolumn{4}{|c|}{ Skoring } & \multirow{3}{*}{$\begin{array}{c}\text { Total } \\
\text { Skori } \\
n g \\
(\%)\end{array}$} & \multirow{3}{*}{$\begin{array}{c}\text { Kategor } \\
\text { Beban } \\
\text { Kerja }\end{array}$} \\
\hline & Input & Central & Output & Time & & \\
\hline & $\begin{array}{c}\text { Deman } \\
d\end{array}$ & $\begin{array}{c}\text { Deman } \\
d\end{array}$ & $\begin{array}{c}\text { Deman } \\
d\end{array}$ & $\begin{array}{c}\text { Pressur } \\
e\end{array}$ & & \\
\hline \multirow{2}{*}{1} & $59 \times 25$ & $64,5 \times 35$ & $58 \times 20$ & $66 \times 20$ & 62,12 & Over \\
\hline & 1475 & 2257,5 & 1160 & 1320 & 5 & Load \\
\hline \multirow{2}{*}{2} & $17,5 \times 20$ & $20 \times 31$ & $12,5 \times 32$ & $12,5 \times 17$ & 15,82 & Under \\
\hline & 350 & 620 & 400 & 212,5 & 5 & Load \\
\hline 3 & $15 \times 20$ & $17,5 x$ & $30 \times 30$ & $25 \times 20$ & 22,25 & Under \\
\hline
\end{tabular}

\begin{tabular}{|c|c|c|c|c|c|c|}
\hline & & 30 & & & & Load \\
\hline & 300 & 5250 & 900 & 500 & & \\
\hline \multirow{2}{*}{4} & $80,1 \times 25$ & $70,1 \times 25$ & $80,1 \times 25$ & $\begin{array}{c}80,1 \times x \\
25\end{array}$ & \multirow{2}{*}{77,6} & \multirow{2}{*}{$\begin{array}{l}\text { Over } \\
\text { Load }\end{array}$} \\
\hline & 2002,5 & 1752,5 & 2002,5 & 2002,5 & & \\
\hline \multirow{2}{*}{5} & $80,1 \times 25$ & $80,1 \times 25$ & $80,1 \times 25$ & $80,1 \times 25$ & \multirow{2}{*}{80,1} & \multirow{2}{*}{$\begin{array}{l}\text { Over } \\
\text { Load }\end{array}$} \\
\hline & 2002,5 & 2002,5 & 2002,5 & 2002,5 & & \\
\hline \multirow[t]{2}{*}{6} & $85,5 \times 25$ & $78 \times 25$ & $85,5 \times 25$ & $85,5 \times 25$ & \multirow{2}{*}{$\begin{array}{c}83,62 \\
5 \\
\end{array}$} & \multirow{2}{*}{$\begin{array}{l}\text { Over } \\
\text { Load }\end{array}$} \\
\hline & 2137,5 & 1950 & 2137,5 & 2137,5 & & \\
\hline 7 & $\frac{80 \times 30}{2400}$ & $\frac{100 \times 30}{3000}$ & $\frac{80 \times 30}{2400}$ & $\frac{90 \times 10}{900}$ & 87 & $\begin{array}{l}\text { Over } \\
\text { Load }\end{array}$ \\
\hline \multirow{2}{*}{8} & $20 \times 20$ & $17,5 \times 30$ & $32,5 \times 20$ & $27,5 \times 30$ & \multirow{2}{*}{24} & \multirow{2}{*}{$\begin{array}{l}\text { Under } \\
\text { Load }\end{array}$} \\
\hline & 400 & 525 & 650 & 825 & & \\
\hline 9 & $\begin{array}{c}17,5 \times 20 \\
350\end{array}$ & $\frac{20 \times 30}{600}$ & $\frac{32,5 \times 30}{975}$ & $\frac{35 \times 20}{700}$ & 24,25 & $\begin{array}{l}\text { Under } \\
\text { Load }\end{array}$ \\
\hline \multirow{2}{*}{10} & $15 \times 20$ & $17,5 \times 30$ & $\begin{array}{c}37,55 x \\
30\end{array}$ & $22,5 \times 20$ & \multirow{2}{*}{24,01} & \multirow{2}{*}{$\begin{array}{l}\text { Under } \\
\text { Load }\end{array}$} \\
\hline & 300 & 525 & 1126,5 & 450 & & \\
\hline \multirow{2}{*}{11} & $12,5 \times 20$ & $15 \times 15,5$ & $15 \times 16$ & $12,5 \times 8,5$ & \multirow{2}{*}{8,28} & \multirow{2}{*}{$\begin{array}{l}\text { Over } \\
\text { Load }\end{array}$} \\
\hline & 250 & 232,5 & 240 & 106,25 & & \\
\hline \multirow{2}{*}{12} & $12,5 \times 25$ & $10 \times 20$ & $15 \times 30$ & $10 \times 25$ & \multirow{2}{*}{12,12} & \multirow{2}{*}{$\begin{array}{l}\text { Under } \\
\text { Load }\end{array}$} \\
\hline & 312,5 & 200 & 450 & 250 & & \\
\hline \multirow[t]{2}{*}{13} & $\begin{array}{r}12,5 \times 25 \\
2125\end{array}$ & $12,5 \times 25$ & $10 \times 25$ & $12,5 \times 25$ & 11,87 & \multirow{2}{*}{$\begin{array}{l}\text { Under } \\
\text { Load }\end{array}$} \\
\hline & $\begin{array}{r}312,5 \\
60,1 \times 20\end{array}$ & $\begin{array}{c}312,5 \\
70,1 \times 30\end{array}$ & $\begin{array}{l}31,5 \\
60,1 \times 20\end{array}$ & $\begin{array}{c}31,5 \\
60,1 \times 30\end{array}$ & \multirow{2}{*}{63,1} & \\
\hline 14 & 1202 & 2103 & 1202 & 1803 & & Load \\
\hline 15 & $59 \times 15$ & $59 \times 30$ & $60 \times 25$ & $66,5 \times 30$ & 61.5 & Over \\
\hline & 885 & 1770 & 1500 & 1995 & & Load \\
\hline 16 & $80 \times 25$ & $100 \times 30$ & $80 \times 25$ & $90 \times 15$ & 83,5 & Over \\
\hline & $\frac{2000}{85,5 \times 25}$ & $\frac{3000}{85,5 \times 25}$ & $\frac{2000}{85,5 \times 20}$ & $\frac{1350}{85,5 \times 30}$ & & \\
\hline 17 & 2137,5 & 2137,5 & 1710 & 2565 & 85,5 & Load \\
\hline & & Rata- & & & 48,63 & $\begin{array}{c}\text { Optimal } \\
\text { Load }\end{array}$ \\
\hline
\end{tabular}

Tabel 9 Kategori Beban Kerja Untuk Fireman

\begin{tabular}{|c|c|c|c|c|c|}
\hline \multicolumn{6}{|c|}{ Kategori Beban Kerja } \\
\hline \multirow[b]{2}{*}{ Jabatan } & Beban I & rja Fisik & Beban K & a Mental & \multirow[b]{2}{*}{$\begin{array}{c}\text { Jumlah } \\
(\%)\end{array}$} \\
\hline & $\begin{array}{c}\text { Rata- } \\
\text { Rata } \\
\text { Input } \\
\text { Deman } \\
d \text { (ID) }\end{array}$ & $\begin{array}{l}\text { Rata- } \\
\text { Rata } \\
\text { Output } \\
\text { Deman } \\
d(\mathrm{OD})\end{array}$ & $\begin{array}{c}\text { Rata- } \\
\text { Rata } \\
\text { Central } \\
\text { Deman } \\
d(\mathrm{CD})\end{array}$ & $\begin{array}{c}\text { Rata- } \\
\text { Rata } \\
\text { Time } \\
\text { Pressur } \\
\text { e (TP) }\end{array}$ & \\
\hline Fireman & 22,64 & 25,17 & 27,44 & 22,08 & 100,00 \\
\hline $\begin{array}{l}\text { Total } \\
\text { Rata- } \\
\text { Rata }\end{array}$ & \multicolumn{2}{|c|}{47,81} & \multicolumn{2}{|c|}{49,52} & 100 \\
\hline
\end{tabular}

\section{Analisis Nilai Beban Kerja Supervisor}

Berdasarkan hasil perhitungan pada tabel 5, nilai total skoring dari pada hasil perhitungan rekapitulasi skor beban kerja untuk supervisor di HSE \& QM ditampilkan dalam grafik berikut ini :

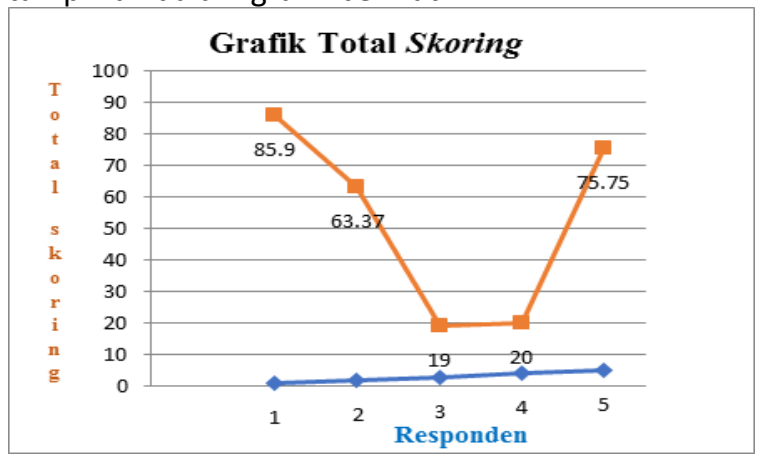

Gambar 1 Grafik Hasil Total Skoring Untuk Supervisor

Grafik diatas menunjukkan hasil perhitungan dari total skoring yang didapat daripada rekapitulasi skor beban kerja untuk pengukuran beban kerja fisik dan mental supervisor di HSE \& QM. Dari 5 responden yang mengisi kuesioner diperoleh 3 responden merasakan over load dan 2 lainnya under load.

Berdasarkan hasil perhitungan yang diperoleh pada tabel 6 menunjukkan bahwa beban kerja yang paling dominan dirasakan supervisor adalah variabel Time 
Pressure sebesar 36\% dengan sebaran beban kerja fisik sebesar $46,8 \%$ dan beban kerja mental sebesar 53,2\%. Jadi beban kerja yang dirasakan lebih banyak oleh supervisor dalam melakukan pekerjannya termasuk kedalam beban kerja mental.

\section{Analisis Faktor Beban Kerja Supervisor}

Hasil kuesioner yang telah dikumpulkan menunjukkan bahwa para supervisor sangat memerlukan usaha mental dalam menyelesaikan pekerjaannya, yang mana alasan yang didapat dari hasil kuesioner menyatakan bahwa untuk pengecekan kinerja karyawan mempunyai sedikit kendala karena kurangnya personel dan harus menunggu laporan dan tindakan dari bawahan, kemudian dalam mengambil keputusan yang tepat diperlukan koordinasi dengan atasan dan untuk pengecekan kinerja daripada karyawan serta memerlukan notes harian agar dapat disimpulkan hasil kinerja dari para bawahan.

\section{Analisis Nilai Beban Kerja Fireman}

Berdasarkan hasil perhitungan pada tabel 7, nilai total skoring dari pada hasil perhitungan rekapitulasi skor beban kerja untuk fireman di HSE \& QM ditampilkan dalam grafik dibawah ini :

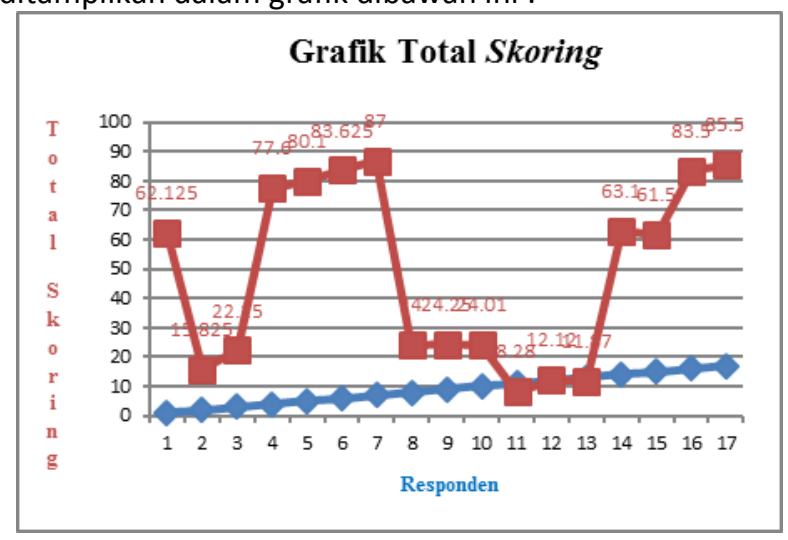

Gambar 2 Grafik Hasil Total Skoring Untuk Fireman

Grafik diatas menunjukkan hasil perhitungan dari total skoring yang didapat daripada rekapitulasi skor beban kerja untuk pengukuran beban kerja fisik dan mental Fireman di HSE \& QM. Dari 17 responden yang mengisi kuesioner diperoleh 10 responden merasakan over load dan 7 lainnya under load.

Berdasarkan hasil perhitungan yang diperoleh pada tabel 8, menunjukkan bahwa beban kerja yang paling dominan dirasakan fireman di HSE \& QM adalah variabel Central Demand sebesar 27,44\% dengan sebaran beban kerja fisik sebesar $47,81 \%$ dan beban kerja mental sebesar $49,52 \%$. Jadi beban kerja yang dirasakan lebih banyak oleh Fireman dalam melakukan pekerjannya termasuk kedalam beban kerja mental.

\section{Analisis Faktor Beban Kerja Fireman}

Hasil kuesioner yang telah dikumpulkan menunjukkan bahwa para Personel Fireman sangat memerlukan usaha mental dalam menyelesaikan pekerjaannya, yang mana rata-rata dari alasan yang diperoleh melalui kuesioner yang telah dibagikan menyatakan bahwa sarana pendukung untuk menyelesaikan laporan agak terbatas dan laporan harus sesuai di akhir bulan, kemudian dalam menyelesaikan pekerjaan para personel harus mempunyai tanggung jawab yang tinggi sesuai dengan jadwal yang telah diberikan dan mengecek alat-alat kerja, serta kontribusi dan komunikasi dengan pihak ketiga bisa menjadi tolak ukur selesainya suatu pekerjaan secara tepat waktu.

\section{Kesimpulan}

Adapun kesimpulan yang didapatkan daripada penelitian yang dilakukan yaitu sebagai berikut :

1. Beban kerja yang dirasakan oleh supervisor melalui pengukuran beban kerja DRAWS adalah optimal load dengan rata-rata skor beban kerja sebesar 52,80\%, sedangkan beban kerja yang dirasakan oleh fireman adalah optimal load dengan rata-rata skor beban kerja sebesar 48,63\%, dimana baik supervisor dan fireman dituntut untuk meningkatkan keterampilan dan pengetahuan agar dapat memberikan kontribusi yang baik bagi perusahaan.

2. Variabel beban kerja DRAWS yang paling dominan dirasakan oleh supervisor adalah variabel time pressure sebesar $36 \%$ dengan sebaran beban kerja fisik sebesar $46,8 \%$ dan beban kerja mental sebesar $53,2 \%$. Sedangkan variabel beban kerja yang paling dominan dirasakan oleh fireman adalah Central Demand sebesar 27,44\% dengan sebaran beban kerja fisik sebesar $47,81 \%$ dan beban kerja mental sebesar $49,52 \%$.

\section{Daftar Pustaka}

[1] Nurmianto, "Ergonomi Konsep Dasar dan Aplikasinya," Pengukuran Dan Perenc. Sietem Kerja(Antropometri Dan Desain Produk), 2004.

[2] Z. Fakhriza, M. Rahayu, and M. Iqbal, "Design improvement of automated gallon washing machine to minimize musculoskeletal disorders (MSDs) in CV Barokah Abadi using ergonomic function deployment (EFD) approach," in IOP Conference Series: Materials Science and Engineering, 2017.

[3] P. Prof. Dr. dr. Anies, M.Kes, "Penyakit Akibat Kerja," Seri Kesehat. Umum, 2005.

[4] D. Abdullah, "Potensi teknologi informasi dan komunikasi dalam peningkatan mutu pembelajaran di kelas," Potensi Teknologi Informasi Dan Komunikasi Dalam Peningkatan Mutu Pembelajaran Di Kelas. 2009.

[5] D. Abdullah, I. Erliana, and I. Kamal, "Identifikasi Gender Melalui Suara Dengan Metode Statistik Ciri Orde Pertama," IJNS - Indones. J. Netw. Secur., 2015.

[6] D. Abdullah et al., "A Slack-Based Measures within Group Common Benchmarking using DEA for Improving the Efficiency Performance of 
Departments in Universitas Malikussaleh," MATEC Web Conf., 2018.

[7] D. Napitupulu et al., "User Acceptance Study on Academic Information System in University XYZ," 2018.

[8] "PENGELOLAAN LIMBAH MEDIS PADAT PADA PUSKESMAS KABUPATEN PATI," KESMAS - J. Kesehat. Masy., 2013.

[9] C. I. Erliana, D. Irwansyah, D. Abdullah, M. Zarlis, and E. Elviwani, "ANALISIS TINGKAT KEBISINGAN PADA DEPARTEMENT FIBER LINE DI PT. TOBA PULP LESTARI," TECHSI - J. Tek. Inform., 2018.

[10] T. Trisna, C. I. Erliana, and R. Lestari, "PEMETAAN DAN PENGARUH KEBISINGAN TERHADAP KELELAHAN KERJA KARYAWAN PADA BAGIAN FIBERLINE DI INDUSTRI PEMBUATAN BUBUR KERTAS," J. Sist. Tek. Ind., 2018.

[11] S. K. Trisnawati and S. Setyorogo, "Faktor Risiko Kejadian Diabetes Melitus Tipe II Di Puskesmas Kecamatan Cengkareng Jakarta Barat Tahun 2012," J. IIm. Kesehat., 2013.

[12] S. Ramli and D. I. Jambari, "Capacity Planning for Green Data Center Sustainability," Int. J. Adv. Sci. Eng. Inf. Technol., 2018.

[13] Republik Indonesia, "Peraturan Pemerintah Republik Indonesia Nomor 19 tahun 2005 tentang standar nasional pendidikan," Peratur. Pemerintah Republik Indones., 2005.

[14] M. F. Syahputra et al., "Implementation of augmented reality to train focus on children with $\mathrm{s}$ pecial needs," in Journal of Physics: Conference Series, 2018.

[15] S. Ramadhani, U. Anis, and S. T. Masruro, "Rancang Bangun Sistem Informasi Geografis Layanan Kesehatan Di Kecamatan Lamongan Dengan PHP MySQL," J. Tek., 2013.

[16] S. G. Mastan, M. S. Rathore, S. Kumari, R. P. Muppala, and N. Kumar, "Genetic Engineering for the Improvement of Oil Content and Associated Traits in Jatropha curcas L.," in Jatropha, Challenges for a New Energy Crop, 2019.

[17] E. Kurniawan and Z. Arsyad, "Artikel Penelitian Nilai Diagnostik Metode 'Real Time' PCR GeneXpert pada TB Paru BTA Negatif,” J. Kesehat. Andalas, 2016.

[18] P. Farmer, "An Anthropology of Structural Violence," Curr. Anthropol., 2004.

[19] T. N. Bauer et al., "Journal of Management," in In Search Of Research Excellence: Exemplars in Entrepreneurship, 2011.

[20] S. P. Osborne, Z. Radnor, and G. Nasi, "A New Theory for Public Service Management? Toward a (Public) Service-Dominant Approach," Am. Rev. Public Adm., 2013. 